\title{
Porphyromonas gingivicanis sp. nov. and Porphyromonas crevioricanis sp. nov., Isolated from Beagles
}

\author{
MASATOMO HIRASAWA* AND KAZUKO TAKADA \\ Department of Microbiology, Nihon University School of Dentistry at Matsudo, Matsudo, Chiba 271, Japan
}

\begin{abstract}
Two new species, Porphyromonas gingivicanis and Porphyromonas crevioricanis, are proposed for blackpigmented, asaccharolytic, anaerobic, nonmotile, non-spore-forming, gram-negative, rod-shaped organisms. These organisms were isolated from the gingival crevicular fluids of beagles. $P$. gingivicanis and $P$. crevioricanis do not grow in the presence of $20 \%$ bile. They exhibit less than 5\% DNA-DNA homology with the type strains of Porphyromonas gingivalis (strain ATCC 33277), Porphyromonas endodontalis (strain ATCC 35406), and Porphyromonas asaccharolytica (strain ATCC 25260), which were isolated from humans, or with the type strains of Porphyromonas salivosa (strain NCTC 11632) and Porphyromonas circumdentaria (strain NCTC 12469), which were isolated from cats. The major cellular fatty acid of $P$. gingivicanis and $P$. crevioricanis is 13 methyltetradecanoic acid (iso- $\mathrm{C}_{15: 0}$ acid). Glutamate and malate dehydrogenases are present in both species, and 6-phosphogluconate and glucose-6-phosphate dehydrogenases are absent; neither organism exhibits trypsin activity. $P$. gingivicanis and $P$. crevioricanis produce large amounts of acetic and isovaleric acids and minor amounts of isobutyric and succinic acids as end products of metabolism in GAM medium. $P$. gingivicanis also produces large amounts of butyric acid and small amounts of propionic acid, while $P$. crevioricanis produces large amounts of propionic acid and minor amounts of butyric and phenylacetic acids. The $G+C$ contents of the DNA of $P$. gingivicanis is 41 to $42 \mathrm{~mol} \%$; the G+C content of the DNA of $P$. crevioricanis is 44 to $45 \mathrm{~mol} \%$. Catalase is produced by $P$. gingivicanis but not by $P$. crevioricanis; strains of $P$. crevioricanis agglutinate sheep erythrocytes, but strains of $P$. gingivicanis do not. The type strain of $P$. gingivicanis is NUM 301 (= ATCC 55562), and the type strain of $P$. crevioricanis is NUM 402 (= ATCC 55563).
\end{abstract}

Beagles are commonly used in periodontal disease research since periodontal disease can be experimentally induced in beagle gingival tissues $(4,5,17)$. The microbial flora associated with this disease has also been extensively studied $(20,21)$. During our studies of the microbial flora in the gingival crevicular fluids of beagles, we isolated a large number of asaccharolytic, black-pigmented, anaerobic bacteria which have unique characteristics compared with the Porphyromonas species isolated from humans (18).

In this paper, we describe the physiological, serological, and biochemical characteristics of these new strains. On the basis of our findings, we propose that two new species in the genus Porphyromonas should be created for these bacteria. The results of comparative physiological, serological, and biochemical tests are summarized below.

\section{MATERIALS AND METHODS}

Bacterial strains. A total of 95 strains were isolated from 13 gingival crevicular fluid samples obtained from 13 beagles. Isolation and initial characterization of these microorganisms were carried out by the procedures described by Laliberté and Mayrand (10). The strains were maintained on GAM agar (Nissui, Tokyo, Japan) supplemented with 5\% rabbit blood, $0.05 \%$ hemin, and $0.01 \%$ menadione in an atmosphere containing $80 \% \mathrm{~N}_{2}, 10 \% \mathrm{CO}_{2}$, and $10 \% \mathrm{H}_{2}$. To compare our new strains with the previously described Porphyromonas species isolated from humans and cats, we obtained Porphyromonas gingivalis ATCC $33277^{\mathrm{T}}(\mathrm{T}=$ type strain), Porphyromonas endodontalis ATCC $35406^{\mathrm{T}}$, and Porphyromonas asaccharolytica ATCC $25260^{\mathrm{T}}$ from the American Type Culture Collec-

* Corresponding author. Mailing address: Department of Microbiology, Nihon University School of Dentistry at Matsudo, 2-870-1 Sakaecho-Nishi, Matsudo, 271, Japan. Phone: 81-473-68-6111. Fax: 81-473-64-6295. tion (ATCC) and Porphyromonas salivosa $\mathrm{NCTC} 11632^{\mathrm{T}}$ and Porphyromonas circumdentaria NCTC $12469^{\mathrm{T}}$ from the National Collection of Type Cultures (NCTC).

Physiological and biochemical characterization. The methods used for general biochemical characterization, as well as the methods used to determine volatile fatty acid contents and methylation of nonvolatile fatty acids, were the procedures described in the Anaerobe Laboratory Manual (7) and in the instructions for the Minitek anaerobic system (BBL Microbiology Systems, Cockeysville, Md.). The compounds used in the fermentation assays were glucose, sucrose, lactose, cellobiose, mannose, arabinose, trehalose, and xylose. Phenylacetic acid was detected in methylated samples as described by Assche (1). The fatty acids of whole bacterial cells were prepared and analyzed by the method described by Moore et al. (15). A Shimadzu model GC-9A gas chromatograph equipped with a flame ionization detector and a model Chromatopac C-R3A integrator (Shimadzu Co., Tokyo, Japan) were used for detection. The organic phase was chromatographed on a $3 \%$ OV-225 column $(0.3$ by $300 \mathrm{~cm}$; Shimadzu Co.). For fatty acid identification, a bacterial acid methyl ester CP mixture (Matreya, Inc., Pleasant Gap, Pa.) was used as the standard. Production of catalase was tested by adding a few drops of $30 \%$ $\mathrm{H}_{2} \mathrm{O}_{2}$ to cell suspensions (7). Menadione and hemin requirements were determined by using brain heart infusion (Difco Laboratories, Detroit, Mich.) agar plates without menadione or hemin for three passages (22). Hemagglutination activity was determined with 48 -h cultures in microtiter plates containing sheep erythrocytes, and the results were scored on a scale from 0 to $3+(10)$. Susceptibility of the isolates to penicillin, amoxicillin, sulbenicillin, and erythromycin was determined with antibiotic disks (Eiken Chemical Co., Ltd. Tokyo, Japan).

Serological and enzymatic characterization. Formation of antigen-antibody complexes was determined by an agar gel diffusion method, using $1.2 \%$ agarose in 0.033 -ionic strength Veronal buffer ( $\mathrm{pH}$ 8.6). Enzymatic activities were determined 
by using the API ZYM system (Analytab Products, Plainview, N.Y.) $(6,11)$.

Isolation of DNA. DNA was extracted from cells grown in 1 liter of GAM broth supplemented with menadione and hemin. The cells were harvested by centrifugation and then suspended in a $0.15 \mathrm{M} \mathrm{NaCl}-10.01 \mathrm{M}$ EDTA-salt solution $(\mathrm{pH} 8.0)$. The cells were lysed by adding sodium dodecyl sulfate to a final concentration of $1 \%$. The DNA was then extracted and purified by the method described by Marmur and Doty (14).

Determination of the $\mathbf{G}+\mathbf{C}$ contents of DNAs. The guanineplus-cytosine $(\mathrm{G}+\mathrm{C})$ contents of the DNA preparations were determined by the high-performance liquid chromatography (HPLC) method (9). Briefly, $10 \mu \mathrm{g}$ of denatured DNA was hydrolyzed with $\mathrm{P} 1$ nuclease $(50 \mu \mathrm{g} / \mathrm{ml}$ in $50 \mathrm{mM}$ acetate buffer containing $0.1 \mathrm{mM} \mathrm{ZnCl} 2$ [pH 5.3]; Yamasa Shoyu Co., Ltd., Chiba, Japan) for $2 \mathrm{~h}$ at $50^{\circ} \mathrm{C}$. Alkaline phosphatase $(2.4 \times$ $10^{-2}$ U; Takara Shuzo Co., Ltd., Tokyo, Japan) was then added, and the mixture was incubated at $37^{\circ} \mathrm{C}$ for $1 \mathrm{~h}$. The nucleosides were separated and quantified with a model 510 HPLC system (Waters, Millipore Co., Bedford, Mass.) and a Nova-Pak C18 column (Waters) by using an equal amount of a nucleoside mixture (Yamasa, Tokyo, Japan) as a standard. The nucleosides were eluted with a solvent containing $0.2 \mathrm{M}$ $\mathrm{NH}_{4} \mathrm{H}_{2} \mathrm{PO}_{4}$ and acetonitrile (20:1, vol/vol).

Assessment of DNA-DNA homology. Dot blot hybridization on nitrocellulose filters in which photobiotin-labeled DNA was used was performed by the method described by Ezaki et al. (3). Briefly, $5 \mu$ l of photobiotin (Pierce, Rockford, Ill.) was mixed with an equal volume of a heat-denatured DNA solution ( $5 \mu \mathrm{g}$ of DNA) in an Eppendorf tube. This mixture was then irradiated with a sun lamp $(500 \mathrm{~W})$ for $15 \mathrm{~min}$. After irradiation, free photobiotin was removed by 2-butanol extraction. The biotinylated DNA was used for dot blot hybridization.

Allozyme electrophoresis. Cells were harvested from 2-dayold culture plates and were suspended in sterile water. Electrophoresis on Cellogel (Seikagaku Co., Tokyo, Japan) was carried out by using supernatants from sonicated cell preparations. The method described by Richardson et al. (16) and Shah and Williams (19) was used to determine the presence of enzymes which are involved in the metabolic pathway. End points of reactions were read after no more than $15 \mathrm{~min}$.

\section{RESULTS AND DISCUSSION}

The 95 Porphyromonas strains isolated from the gingival crevicular fluids of beagles were separated into three groups (19 strains were members of group 1, 71 strains were members of group 2,3 strains were members of group 3, and 2 strains did not belong to any group) on the basis of the results of physiological and biochemical characterization tests (Tables 1 through 3). Nonfermentative metabolism distinguishes these organisms from the genus Prevotella, and the absence of glucose-6-phosphate dehydrogenase and 6-phosphogluconate dehydrogenase and the presence of iso- $\mathrm{C}_{15: 0}$ as the major cellular fatty acid distinguish them from the Bacteroides fragilis group. Also, our isolates are biochemically and morphologically different from other nonfermentative gram-negative anaerobic rods, including Bilophila, Desulfomonas, Dichelobacter, and Tissierella species. Bilophila, Desulfomonas, Dichelobacter, and Tissierella strains do not produce a black pigment, while the strains which we studied do produce a characteristic black pigment. Our strains do not grow in media containing $20 \%$ bile and are not susceptible to kanamycin, while Bilophila strains can grow under these culture conditions and are susceptible to kanamycin. Furthermore, our isolates are indole positive and do not form colonies with spreading
TABLE 1. Characteristics of Porphyromonas strains isolated from gingival crevicular fluids of beagles and Porphyromonas type strains

\begin{tabular}{|c|c|c|c|c|}
\hline \multicolumn{3}{|c|}{ Organism } & \multirow{2}{*}{$\begin{array}{l}\text { End products in } \\
\text { GAM broth }\end{array}$} & \multirow{2}{*}{$\begin{array}{c}\mathrm{G}+\mathrm{C} \\
\text { content } \\
\text { (mol\%) }\end{array}$} \\
\hline Group & Species & Strain & & \\
\hline \multirow[t]{4}{*}{1} & P. gingivicanis & NUM $301^{\mathrm{T}}$ & $\mathrm{A}, \mathrm{p}, \mathrm{B}, \mathrm{ib}, \mathrm{IV}, \mathrm{s}$ & $41-42$ \\
\hline & & NUM 308 & $\mathrm{~A}, \mathrm{p}, \mathrm{B}, \mathrm{ib}, \mathrm{IV}, \mathrm{s}$ & $41-42$ \\
\hline & & NUM 313 & A,p,B,ib,IV,s & $41-42$ \\
\hline & & NUM 325 & $\mathrm{~A}, \mathrm{p}, \mathrm{B}, \mathrm{ib}, \mathrm{IV}, \mathrm{s}$ & $41-42$ \\
\hline \multirow[t]{4}{*}{2} & P. crevioricanis & NUM $402^{\mathrm{T}}$ & $\mathrm{A}, \mathrm{P}, \mathrm{b}, \mathrm{ib}, \mathrm{IV}, \mathrm{s}, \mathrm{pa}$ & $44-45$ \\
\hline & & NUM 408 & $\mathrm{~A}, \mathrm{P}, \mathrm{b}, \mathrm{ib}, \mathrm{IV}, \mathrm{s}, \mathrm{pa}$ & $44-45$ \\
\hline & & NUM 415 & $\mathrm{~A}, \mathrm{P}, \mathrm{b}, \mathrm{ib}, \mathrm{IV}, \mathrm{s}, \mathrm{pa}$ & $44-45$ \\
\hline & & NUM 427 & $, I V, s, p a$ & $44-45$ \\
\hline \multirow[t]{6}{*}{3} & & NUM 501 & $\mathrm{~A}, \mathrm{~B}, \mathrm{ib}, \mathrm{IV}, \mathrm{S}, \mathrm{pa}$ & $44-45$ \\
\hline & P. salivosa & NCTC $11632^{\mathrm{T}}$ & A,B,IV,S,PA & $42-44^{b}$ \\
\hline & P. circumdentaria & NCTC $12469^{\mathrm{T}}$ & A,B,IV,S,pa & $40-42^{b}$ \\
\hline & P. gingivalis & ATCC $33277^{\mathrm{T}}$ & A,B,IV,S,PA & $48-49$ \\
\hline & $P$. endodontalis & ATCC $35406^{\mathrm{T}}$ & $\mathrm{a}, \mathrm{b}, \mathrm{ib}, \mathrm{iv}^{b}$ & $49-50$ \\
\hline & P. asaccharolytica & ATCC $25260^{\mathrm{T}}$ & $\mathrm{A}, \mathrm{P}, \mathrm{B}, \mathrm{IB}, \mathrm{IV}^{b}$ & $53-54$ \\
\hline
\end{tabular}

${ }^{a}$ GAM broth was obtained from Nissui. Abbreviations: $A$ and a, acetic acid; $B$ and $b$, butyric acid; IB and ib, isobutyric acid; IV and iv, isovaleric acid; P and $\mathrm{p}$, propionic acid; $\mathrm{S}$ and $\mathrm{s}$, succinic acid; $\mathrm{PA}$ and $\mathrm{pa}$, phenylacetic acid. Uppercase letters indicate major amounts $(\geq 15 \mu \mathrm{mol} / \mathrm{ml}$ ), and lowercase letters indicate minor amounts $(<15 \mu \mathrm{mol} / \mathrm{ml})$.

${ }^{b}$ Data from reference 12 .

edges, while Dichelobacter strains do not produce indole and spreading of Dichelobacter colonies does occur. Finally, the $\mathrm{G}+\mathrm{C}$ contents of our strains are quite different from the $\mathrm{G}+\mathrm{C}$ contents of Tissierella and Desulfomonas strains. The strains isolated from beagles are therefore members of the genus Porphyromonas. These Porphyromonas strains are distinctly different from the type strains of $P$. gingivalis (strain ATCC 33277), $P$. endodontalis (strain ATCC 35406), and $P$. asaccharolytica (strain ATCC 25260), which were isolated from humans. Furthermore, our Porphyromonas strains are also different from the recently isolated cat strains $P$. salivosa NCTC $11632^{\mathrm{T}}(12,13)$ and $P$. circumdentaria NCTC $12469^{\mathrm{T}}(12)$ (Table 2). As Table 1 shows, the $\mathrm{G}+\mathrm{C}$ contents of group 1 strains, including strains NUM 301 ${ }^{\mathrm{T}}$, NUM 308, NUM 313, and NUM 325, which do not produce phenylacetic acid, are 41 to $42 \mathrm{~mol} \%$, and the $\mathrm{G}+\mathrm{C}$ contents of group 2 and 3 strains, including strains NUM 402' , NUM 408, NUM 415, NUM 427, and NUM 501, which produce phenylacetic acid, are 44 to 45 mol\%. The $\mathrm{G}+\mathrm{C}$ contents of members of groups 1 through 3 are similar to those of Porphyromonas strains isolated from cats (Table 1). Previously, Coykendall et al. described the $\mathrm{G}+\mathrm{C}$ contents of two dog strains; the $\mathrm{G}+\mathrm{C}$ content of one strain was $42 \mathrm{~mol} \%$, and the $\mathrm{G}+\mathrm{C}$ content of the other was $48 \mathrm{~mol} \%$ (2). Also, most of the catalase-positive dog strains described previously produced phenylacetic acid (8). Laughon et al. (11) described beagle strains which may or may not have trypsin activity, $\alpha$-glucosidase activity, or $N$-acetyl- $\beta$-glucosaminidase activity. Laliberté and Mayrand (10), who described 20 isolates obtained from 10 dogs, found that their strains were catalase positive, hemagglutinated erythrocytes, and had trypsin activity. However, in all of these cases, the descriptions of the biochemical parameters of the Porphyromonas strains isolated from nonprimate sources were incomplete. Table 2 shows the DNA-DNA homology results for representative strains isolated from beagles, human strains, and cat strains. Dot blot hybridization studies showed that group 1,2 , or 3 organisms exhibited levels of DNA-DNA homology of less than $5 \%$ with $P$. gingivalis ATCC $33277^{\mathrm{T}}, P$. as accharolytica ATCC $25260^{\mathrm{T}}, P$. endodontalis ATCC $35406^{\mathrm{T}}, P$. salivosa NCTC $11632^{\mathrm{T}}$, and $P$. 
TABLE 2. Levels of DNA-DNA homology for Porphyromonas type strains and strains isolated from beagles

\begin{tabular}{|c|c|c|c|c|c|c|c|c|}
\hline \multicolumn{3}{|c|}{ Unlabeled DNA from: } & \multicolumn{6}{|c|}{ Level of homology with labeled DNA from $\operatorname{strain}^{a}$ : } \\
\hline Group & Species & Strain & NUM $301^{\mathrm{T}}$ & NUM $402^{\mathrm{T}}$ & NUM 501 & $\begin{array}{l}\text { ATCC } \\
33277^{\mathrm{T}}\end{array}$ & $\begin{array}{l}\text { ATCC } \\
35406^{\mathrm{T}}\end{array}$ & $\begin{array}{l}\text { ATCC } \\
25260^{\mathrm{T}}\end{array}$ \\
\hline \multirow[t]{4}{*}{1} & $P$. gingivicanis & NUM $301^{\mathrm{T}}$ & A & $\mathrm{E}$ & $\mathrm{E}$ & $\mathrm{E}$ & $\mathrm{E}$ & $\mathrm{E}$ \\
\hline & & NUM 308 & A & $\bar{E}$ & $\mathrm{E}$ & $\mathrm{E}$ & $\mathrm{E}$ & $\mathrm{E}$ \\
\hline & & NUM 313 & A & $\mathrm{E}$ & $\mathrm{E}$ & $\mathrm{E}$ & $E$ & E \\
\hline & & NUM 325 & A & $\mathrm{E}$ & $\mathrm{E}$ & $\mathrm{E}$ & $\mathrm{E}$ & $\mathrm{E}$ \\
\hline \multirow[t]{4}{*}{2} & P. crevioricanis & NUM $402^{\mathrm{T}}$ & $\mathrm{E}$ & A & $\mathrm{D}$ & $\mathrm{E}$ & $\mathrm{E}$ & $\mathrm{E}$ \\
\hline & & NUM 408 & $\mathrm{E}$ & A & $\mathrm{D}$ & $\mathrm{E}$ & $\mathrm{E}$ & $\mathrm{E}$ \\
\hline & & NUM 415 & $E$ & A & $\mathrm{D}$ & $\mathrm{E}$ & $\mathrm{E}$ & $\bar{E}$ \\
\hline & & NUM 427 & E & A & D & $\mathrm{E}$ & $\mathrm{E}$ & E \\
\hline \multirow[t]{6}{*}{3} & & NUM 501 & $\mathrm{E}$ & $\mathrm{D}$ & A & $\mathrm{E}$ & $\mathrm{E}$ & $\mathrm{E}$ \\
\hline & P. salivosa & NCTC $11632^{\mathrm{T}}$ & $\mathrm{E}$ & $\mathrm{E}$ & $\mathrm{E}$ & $\mathrm{E}$ & $\mathrm{E}$ & $\mathrm{E}$ \\
\hline & $P$. circumdentaria & NCTC $12469^{\mathrm{T}}$ & $\mathrm{E}$ & $\mathrm{E}$ & $\mathrm{E}$ & $\mathrm{E}$ & $\mathrm{E}$ & $\mathrm{E}$ \\
\hline & $P$. gingivalis & ATCC $33277^{\mathrm{T}}$ & $\mathrm{E}$ & $\mathrm{E}$ & $\mathrm{E}$ & A & $\mathrm{E}$ & $\mathrm{E}$ \\
\hline & P. endodontalis & ATCC $35406^{\mathrm{T}}$ & $\mathrm{E}$ & $\mathrm{E}$ & $\mathrm{E}$ & $\mathrm{E}$ & A & $\mathrm{E}$ \\
\hline & P. asaccharolytica & ATCC $25260^{\mathrm{T}}$ & $\mathrm{E}$ & $\mathrm{E}$ & $E$ & $\mathrm{E}$ & $\mathrm{E}$ & $\bar{A}$ \\
\hline
\end{tabular}

${ }^{a}$ The following five DNA relatedness classes were defined: A, 75 to $100 \%$ homology; B, 50 to $75 \%$ homology; C, 25 to $50 \%$ homology; D, 5 to $25 \%$ homology; and E, $<5 \%$ homology.

circumdentaria NCTC $12469^{\mathrm{T}}$. Group 1 strains also exhibited less than 5\% DNA-DNA homology with group 2 and 3 strains. Group 2 and 3 strains exhibited 5 to $25 \%$ DNA-DNA homology with group 3 and 2 strains, respectively.

The antisera against group 1, 2, and 3 strains formed no detectable precipitates with sonic extracts of $P$. gingivalis, $P$. asaccharolytica, $P$. endodontalis, $P$. salivosa, and $P$. circumdentaria and reacted with antigens to the group 1, 2, and 3 strains, respectively (data not shown). Also, sera against the other members of the genus Porphyromonas yielded no lines of precipitation with group 1,2 , or 3 strains (data not shown). These data indicate that serological dissimilarity might differentiate Porphyromonas species obtained from humans and cats.

Phenotypic characteristics that differentiate $P$. gingivicanis and $P$. crevioricanis from other Porphyromonas species are shown in Table 3. The unique characteristics of $P$. gingivicanis include production of catalase, lack of phenylacetic acid production, absence of trypsin, and no hemagglutination of sheep erythrocytes. The distinguishing characteristics of $P$. crevioricanis include lack of catalase production, trypsin activity, production of phenylacetic acid, and hemagglutination.

Group 3 strains are positive for catalase, trypsin, and $N$-acetyl- $\beta$-glucosaminidase activities and do not agglutinate erythrocytes or produce propionic acid. Since group 3 isolates are rather uncommon, description of a new species for these organisms will have to await isolation of additional strains and determination of additional distinguishing characteristics.

Thus, because groups 1 and 2 are distinct groups of strains from the oral cavities of beagles, we propose that strain NUM
301 (a representative of group 1) and strain NUM 402 (a representative of group 2) should be designated the type strains of distinct species in the genus Porphyromonas. Descriptions of these taxa are given below.

Description of Porphyromonas gingivicanis sp. nov. Porphyromonas gingivicanis (gin.gi.vi.ca'nis. L. fem. n. gingiva, the gums; L. gen. n. canis, of a dog; N. L. gen. n. gingivicanis, of the gums of a dog, because the organism was first isolated from gums of dogs). Isolated from gingival crevicular fluids obtained from beagles. Cells are obligately anaerobic, nonmotile, gram negative, and rod shaped (or coccoid) and do not form spores On rabbit blood agar plates, the average size of cells is $0.5 \mu \mathrm{m}$ by $1.0 \mu \mathrm{m}$ in diameter, and the cells occur singly. After $72 \mathrm{~h}$ of incubation, surface colonies are 0.8 to $1.5 \mathrm{~mm}$ in diameter, circular, entire, dome shaped, opaque, and brown or black. Vitamin $\mathrm{K}$ and hemin are required for growth. Carbohydrate fermentation is not detected in medium containing glucose, mannose, lactose, sucrose, cellobiose, trehalose, xylose, or arabinose. The $\mathrm{G}+\mathrm{C}$ content of the DNA is 41 to $42 \mathrm{~mol} \%$. The major fermentation products in GAM broth are acetic acid (average, $43.4 \mu \mathrm{mol} / \mathrm{ml}$ ), butyric acid (average, 31.9 $\mu \mathrm{mol} / \mathrm{ml}$ ), and isovaleric acid (average, $21.0 \mu \mathrm{mol} / \mathrm{ml}$ ). Smaller quantities of isobutyric acid (average, $8.5 \mu \mathrm{mol} / \mathrm{ml}$ ), succinic acid (average, $8.3 \mu \mathrm{mol} / \mathrm{ml}$ ), and propionic acid (average, 1.4 $\mu \mathrm{mol} / \mathrm{ml}$ ) are produced. iso- $\mathrm{C}_{15: 0}$ acid is the major cellular fatty acid. Malate and glutamate dehydrogenase activities are present, but 6-phosphogluconate dehydrogenase and glucose6-phosphate dehydrogenase activities are not (Table 1). Does not produce phenylacetic acid when cells are grown in GAM

TABLE 3. Major distinguishing characteristics of $P$. gingivicanis, $P$. crevioricanis, and Porphyromonas type strains

\begin{tabular}{|c|c|c|c|c|c|c|}
\hline \multirow[b]{2}{*}{ Taxon } & \multirow[b]{2}{*}{$\begin{array}{l}\text { Catalase } \\
\text { activity }\end{array}$} & \multirow[b]{2}{*}{$\begin{array}{l}\text { Phenylacetic } \\
\text { acid }\end{array}$} & \multirow[b]{2}{*}{ Hemagglutination } & \multicolumn{3}{|c|}{ Enzyme activities } \\
\hline & & & & Trypsin & $\begin{array}{c}N \text {-acetyl- } \beta \text { - } \\
\text { glucosaminidase }\end{array}$ & $\alpha$-Fucosidase \\
\hline$P$. gingivicanis & + & - & - & - & - & - \\
\hline P. crevionicanis & - & + & ++ & - & - & - \\
\hline$P$. salivosa $\mathrm{NCTC} 11632^{\mathrm{T}}$ & + & + & - & + & + & - \\
\hline P. circumdentaria NCTC $12469^{\mathrm{T}}$ & + & + & - & - & - & - \\
\hline P. gingivalis ATCC $33277^{\mathrm{T}}$ & - & + & +++ & + & + & - \\
\hline P. endodontalis ATCC $35406^{\mathrm{T}}$ & - & - & - & - & - & - \\
\hline P. asaccharolytica ATCC $25260^{\mathrm{T}}$ & - & - & - & - & - & + \\
\hline
\end{tabular}


medium. Catalase positive. Cells neither agglutinate sheep erythrocytes nor exhibit trypsin or $N$-acetyl- $\beta$-glucosaminidase activity. The strains are susceptible to penicillin $(0.5 \mathrm{U} /$ disk $)$, amoxicillin $(2 \mu \mathrm{g} /$ disk $)$, sulbenicillin $(5 \mu \mathrm{g} /$ disk $)$, and erythromycin $(0.5 \mu \mathrm{g} / \mathrm{disk})$. The type strain is NUM 301 (= ATCC 55562).

Description of Porphyromonas crevioricanis sp. nov. Porphyromonas crevioricanis (cre.vi.o.ri.ca'nis. L. n. crevi, crevice; L. n. oris, mouth; L. n. canis, dog; N. L. gen. n. crevioricanis, of the crevice of a dog's mouth). Isolated from gingival crevicular fluids obtained from beagles. Cells are obligately anaerobic, nonmotile, gram negative, and rod shaped (or coccoid) and do not form spores. On rabbit blood agar plates, the average size of cells is $0.5 \mu \mathrm{m}$ by $1.0 \mu \mathrm{m}$ in diameter, and the cells occur singly. After $72 \mathrm{~h}$ of incubation, surface colonies are 0.8 to 1.5 $\mathrm{mm}$ in diameter, circular, entire, dome shaped, opaque, and brown or black. Vitamin $\mathbf{K}$ and hemin are required for growth. Carbohydrate fermentation is not detected in medium containing glucose, mannose, lactose, sucrose, cellobiose, trehalose, xylose, or arabinose. The $\mathrm{G}+\mathrm{C}$ content of the DNA is 44 to 45 mol\%. The major fermentation products in GAM broth are acetic acid (average, $50.9 \mu \mathrm{mol} / \mathrm{ml}$ ), propionic acid (average, $48.0 \mu \mathrm{mol} / \mathrm{ml}$ ), and iso-valeric acid (average, $21.0 \mu \mathrm{mol} / \mathrm{ml}$ ). Smaller quantities of butyric acid (average, $13.2 \mu \mathrm{mol} / \mathrm{ml}$ ), isobutyric acid (average, $9.5 \mu \mathrm{mol} / \mathrm{ml}$ ), succinic acid (average, $6.5 \mu \mathrm{mol} / \mathrm{ml}$ ), and phenylacetic acid (average, $1.4 \mu \mathrm{mol} / \mathrm{ml}$ ) are produced. iso- $\mathrm{C}_{15: 0}$ acid is the major cellular fatty acid. Malate and glutamate dehydrogenase activities are present; but 6-phosphogluconate dehydrogenase and glucose-6-phosphate dehydrogenase activities are not (Table 1). Hemagglutinates sheep erythrocytes, but does not produce catalase or exhibit trypsin, $N$-acetyl $-\beta$-glucosaminidase, and $\alpha$-fucosidase activities. Susceptible to penicillin $(0.5 \mathrm{U} /$ disk $)$, amoxicillin $(2 \mu \mathrm{g} /$ disk), sulbenicillin ( $5 \mu \mathrm{g} /$ disk), and erythromycin $(0.5 \mu \mathrm{g} / \mathrm{disk})$. The type strain is NUM 402 (= ATCC 55563).

\section{ACKNOWLEDGMENT}

We thank T. O. MacAdoo (Virginia Polytechnic Institute and State University, Blacksburg) for the derivations of the species names.

\section{REFERENCES}

1. Assche, P. F. D. 1978. Differentiation of Bacteroides fragilis species by gas chromatographic detection of phenylacetic acid. J. Clin. Microbiol. 8:614-615.

2. Coykendall, A. L., F. S. Kaczmarek, and J. Slots. 1980. Genetic heterogeneity in Bacteroides asaccharolyticus (Holdeman and Moore 1970) Finegald and Barnes 1977 (Approved Lists, 1980) and proposal of Bacteroides gingivalis sp. nov. and Bacteroides macacae (Slots and Genco) comb. nov. Int. J. Syst. Bacteriol. 30:559-564.

3. Ezaki, T., Y. Hashimoto, and E. Yabuuchi. 1989. Fluorometric deoxyribonucleic acid-deoxyribonucleic acid hybridization in microdilution wells as an alternative to membrane filter hybridization in which radioisotopes are used to determine genetic relatedness among bacterial strains. Int. J. Syst. Bacteriol. 39:224-229.

4. Hamp, S. E., J. Lindhe, and G. Heyden. 1972. Experimental gingivitis in the dog. An enzyme histochemical study. Arch. Oral Biol. 17:329-337.

5. Hamp, S. E., J. Lindhe, and H. Loe. 1973. Long term effects of chlorhexidine on developing gingivitis in the beagle dog. J. Periodontal Res. 8:63-70.

6. Hofstad, T. 1980. Evaluation of the API ZYM system for identification of Bacteroides and Fusobacterium species. Med. Microbiol. Immunol. 168:173-177.

7. Holdeman, L. V., E. P. Cato, and W. E. C. Moore. 1977. Anaerobe laboratory manual, 4th ed. Virginia Polytechnic Institute and State University, Blacksburg.

8. Kaczmarek, F., and A. L. Coykendall. 1980. Production of phenylacetic acid by strains of Bacteroides asaccharolyticus and Bacteroides gingivalis (sp. nov.). J. Clin. Microbiol. 12:288-290.

9. Kaneko, T., K. Katoh, M. Fujimoto, M. Kumagai, J. Tamaoka, and Y. Katayama-Fujimura. 1986. Determination of the nucleotide composition of a deoxyribonucleic acid by high-performance liquid chromatography of its enzymatic hydrolysate: a review. J. Microbiol. Methods 4:229-240.

10. Laliberté, M., and D. Mayrand. 1983. Characterization of blackpigmented Bacteroides strains isolated from animals. J. Appl. Bacteriol. 55:247-252.

11. Laughon, B. E., S. A. Syed, and W. J. Loesche. 1982. API ZYM system for identification of Bacteroides spp., Capnocytophaga spp., and spirochetes of oral origin. J. Clin. Microbiol. 15:97-102.

12. Love, D. N., G. D. Bailey, S. Collings, and D. A. Briscoe. 1992. Description of Porphyromonas circumdentaria sp. nov. and reassignment of Bacteroides salivosus (Love, Johnson, Jones, and Calverley 1987) as Porphyromonas (Shah and Collins 1988) salivosa comb. nov. Int. J. Syst. Bacteriol. 42:434-438.

13. Love, D. N., J. L. Johnson, R. F. Jones, and A. Calverley. 1987. Bacteroides salivosus sp. nov., an asaccharolytic black-pigmented Bacteroides species from cats. Int. J. Syst. Bacteriol. 37:307-309.

14. Marmur, J., and P. Doty. 1962. Determination of the base composition of deoxyribonucleic acid from its thermal denaturation temperature. J. Mol. Biol. 5:109-118.

15. Moore, L. V. H., J. L. Johnson, and W. E. C. Moore. 1987. Selenomonas noxia sp. nov., Selenomonas flueggei sp. nov., Selenomonas infelix sp. nov., Selenomonas dianae sp. nov., and Selenomonas artemidis sp. nov., from the human gingival crevice. Int. J. Syst. Bacteriol. 36:271-280.

16. Richardson, B. J., P. R. Baverstock, and M. Adams, 1986. Allozyme electrophoresis. A Handbook for animal systematic and population studies. Academic Press, Sydney, Australia.

17. Schroeder, H. E., and J. Lindhe. 1975. Conversion of established gingivitis in the dog into destructive periodontitis. Arch. Oral Biol. 20:775-782.

18. Shah, H. N., and M. D. Collins. 1988. Proposal for reclassification of Bacteroides asaccharolyticus, Bacteroides gingivalis, and Bacteroides endodontalis in a new genus, Porphyromonas. Int. J. Syst. Bacteriol. 38:128-131.

19. Shah, H. N., and R. A. D. Williams. 1982. Dehydrogenase patterns in the taxonomy of Bacteroides. J. Gen. Microbiol. 128:2955-2965.

20. Syed, S. A., M. Svanberg, and G. Svanberg. 1980. The predominant cultivable dental plaque flora of beagle dogs with gingivitis. J. Periodontal Res. 15:123-136.

21. Syed, S. A., M. Svanberg, and G. Svanberg. 1981. The predominant cultivable dental plaque flora of beagle dogs with periodontitis. J. Clin. Periodontol. 8:45-56.

22. van Steenbergen, T. J. M., A. J. van Winkelhoff, D. Mayrand, D. Grenier, and J. de Graaff. 1984. Bacteroides endodontalis sp. nov., an asaccharolytic black-pigmented Bacteroides species from infected dental root canals. Int. J. Syst. Bacteriol. 34:118-120. 